\title{
Diversity and symbiotic performance of peanut rhizobia from Southeast region of Brazil
}

\author{
Carlos Vergara Torres-Júnior ${ }^{1}$, Jakson Leite ${ }^{1}$, Carolina Etienne de Rosália e Silva Santos ${ }^{2}$, \\ Paulo Ivan Fernandes-Júnior ${ }^{3}$, Jerri Édson Zilli ${ }^{4}$, Norma Gouvêa Rumjanek ${ }^{4}$ and \\ Gustavo Ribeiro Xavier ${ }^{4 *}$ \\ ${ }^{1}$ Departamento de Solos, Instituto de Agronomia. Universidade Federal Rural do Rio de Janeiro, BR 465, Km 07, \\ Seropédica, RJ, CEP 23890-000. Brazil. \\ ${ }^{2}$ Departamento de Agronomia, Universidade Federal Rural de Pernambuco, Recife, PE, CEP 52171-900. Brazil. \\ ${ }^{3}$ Embrapa Semiárido, BR 428, km 152, Zona Rural, CEP 56302-970 Petrolina, PE. Brazil. \\ ${ }^{4}$ Embrapa Agrobiologia, BR 465, Km 07, Seropédica, RJ, CEP 23890-000. Brazil.
}

Accepted 13 January, 2014

\begin{abstract}
The use of peanut as a trap-plant for obtaining rhizobia may result in a high diversity of efficient isolates. This study aimed to evaluate the diversity and symbiotic efficiency of peanut rhizobia from the Southeastern region of Brazil. The bacteria were isolated from nodules of two genotypes in soils from the States of São Paulo and Rio de Janeiro, Brazil. The bacteria were authenticated and evaluated regarding to their symbiotic capacity. The rhizobial diversity was evaluated through their culture characteristics on yeast mannitol agar (YMA) culture media and by polymerase chain reaction Box(PCR). Two selected isolates were characterized phenotypically regarding their capacity to solubilize phosphate, to grow on media with different concentrations of $\mathrm{NaCl}, \mathrm{pH}$ 's and incubation temperatures. For these the 16S rRNA gene sequencing and symbiotic efficiency using non-autoclaved soils were conducted. The majority of the obtained isolates showed rapid growth and acidified the culture medium. Analysis of the isolates through the Box-PCR revealed low similarity to the reference strain indicated for the culture and a large genetic variability of the obtained isolates. The isolates AM 01 and AM 07, which clustered with Bradyrhizobium and Rhizobium genus, respectively, showed a potential for evaluations and a means to recommend new rhizobia strains for peanut.
\end{abstract}

Key words: Arachis hypogaea L., inoculant, biological nitrogen fixation.

\section{INTRODUCTION}

The peanut (Arachis hypogaea L.) is a legume that belongs to Papilonoideae subfamily which originated from South-America (Hancock, 2004). This specie offers several uses and in Brazil, there are cultivated genotypes for consumption of grains in natura, roasted peanuts or for the production of oil. The main peanut production regions in Brazil are the Southeast and the Northeast where production increases annually, which, today, is about 300 thousand tons, placing Brazil as the world's fifth largest producer (Santos et al., 2012). In the technological package used for peanut cultivation, the handling of fertilizing is very important because the species requires large amounts of diverse nutrients such as $\mathrm{Ca}, \mathrm{P}$ and $\mathrm{N}$. The supply of nitrogen can occur by means of biological nitrogen fixation (BNF) through symbiosis with efficient rhizobia dispensing or reducing the application of nitrogen fertilizers.

Nowadays, there is a rhizobial strain that has been authorized for the production of inoculants for peanut in Brazil (Brasil, 2011), but inoculation technology of seeds 
with commercial inoculants is still poorly adopted by producers. The reason for this is that the peanut possesses the capacity to nodulate with a great variety of rhizobia native to the Brazilian soil, which frequently reduces positive answers of inoculation (Borges et al., 2007). In this sense, the obtainment of new bacteria with high efficiency and capable of associating themselves with peanut plants in field conditions seems an acceptable strategy to increase the interest of producers in using inoculation techniques.

Over the past few years, prospecting of efficient and competitive rhizobia for peanuts has been carried out systematically (Santos et al., 2007; Lyra et al., 2013), as has been the case for the selection of bacteria for other legumes that are important in Brazil, such as cowpea (Martins et al., 2003; Zilli et al., 2009; Fernandes Júnior et al., 2012) and the common bean (Hungria et al., 2000). Preliminary studies for peanuts that have been conducted in Brazil show genetic and phenotypic variability of the native bacteria (Borges et al., 2007; Santos et al., 2007; Lyra et al., 2013). However, there still is a lack of bacteria with increased efficiency.

The analysis of phenotypic, genetic and ecologic information of the rhizobia isolates is an important stage in the selection process of new isolates since this information contributes to the understanding of the symbiosis between the plant and the bacteria (Garcia-Fraile et al., 2007; Hunter et al., 2007). In addition, the pre-selection of efficient bacteria generates genetic resources for the implementation of new test programs under field conditions for the recommendation of new strains (Lima et al., 2012). In this sense, the objective of this study was to evaluate the phenotypic and genetic diversity, and the symbiotic efficiency of native rhizobia obtained in the southeast of Brazil for peanut crop.

\section{MATERIALS AND METHODS}

\section{Obtainment of nodules and rhizobia isolation}

To obtain the nodules and to isolate the bacteria, an experiment was carried out in pots using six soil samples and the peanut (Arachis hypogaea L.) genotypes BR 1 and BRS Havana as trapplants. The soil samples were collected in the cities of Jaboticabal, Sertãozinho and Taquaritinga at São Paulo State and in an Integrated Agroecological Production System in the municipality of Seropédica in the State of Rio de Janeiro. The samples were collected from the superficial horizon of each area and each sample was composed of at least 6 sub-samples. The land use of the areas at the moment of soil sampling, the class of the soil, its location and fertility characteristics are summarized in Table 1.

The soil samples were broken up, sieved in a $5 \mathrm{~mm}$ sieve and added to polyethylene pots with a capacity of five liters with $4.5 \mathrm{~kg}$ of each soil sample per pot. The seeds were superficially disinfected for sowing with $70 \%$ alcohol for $30 \mathrm{~s}$, with $5 \%$ sodium hypochlorite for $60 \mathrm{~s}$ and washed ten times with sterile distilled water (Vincent, 1970). In each pot three seeds were sown that were exposed to the outside air and 10 days after emergence, thinning was carried out, leaving one plant per pot. An entirely randomized design was used for the installation of the experiment, following a factorial scheme of 6 (soil samples) $\times 2$ (plant genotypes) with four replications. During the experiment, the soil humidity was maintained close to the field capacity, using drinking water, passed through an activated carbon filter. The plants were harvested 50 days after emergence. The roots were separated from the shoot, washed and the nodules were excised and stocked in jars with silica gel for later isolation of bacteria.

At least ten nodules were isolated for each replication (40 nodules per treatment), randomly chosen. The nodules were rehydrated in distilled autoclaved water for $40 \mathrm{~min}$, disinfected superficially with $70 \%$ alcohol for $1 \mathrm{~min}$, with $5 \%$ sodium hypochlorite for three minutes and washed ten times with sterilized distilled water. With a pincer, the disinfected nodules were pressed on a Petri dish containing yeast-mannitol-agar medium (YMA) (Vincent, 1970) with Congo red (Somasegaran and Hoben, 1994). The dishes were incubated at $28^{\circ} \mathrm{C}$ until the appearance of the bacterial colonies. To purify the isolates, the cultures were inoculated successive times to YMA media containing bromothymol blue as $\mathrm{pH}$ indicator to obtain pure cultures. The pure cultures were stored in $\mathrm{YM}$ media containing glycerol $(1: 1 \mathrm{v} / \mathrm{v})$ at $-80^{\circ} \mathrm{C}$.

\section{Evaluation of the diversity of the isolates}

The following properties were observed for the phenotypic characterization of the isolates in YMA media with bromothymol blue (Vincent, 1970): growth time in days of the isolated colonies (fast: until three days; intermediate: four to five days and slow: more than six days), change of medium $\mathrm{pH}$ (acid, neutral and alkaline), size $(<1 \mathrm{~mm}$, between 1 and $2 \mathrm{~mm}$ or $>2 \mathrm{~mm}$ ), transparency (translucent or opaque), elevation (plain and convex), color (white or yellow), shape (circular, oval or irregular) and border (smooth or irregular) of the colonies; appearance of the mucus and the colony (homogeneous or heterogeneous) and the type of mucus, which is classified as butyric and viscous mucus (Martins, 1996).

The isolates AM 01, AM 07 and the strain SEMIA 6144, were evaluated for their capacity to solubilize calcium phosphate "in vitro", for which the GL medium (Sylvester-Bradley et al., 1982) with two distinct carbon sources (mannitol and glucose) was used, as well as for their growth capacity on YMA media with different $\mathrm{pH}$ levels $(4 ; 5 ; 7 ; 9$ and 11$)$, incubation temperatures (39 and $45^{\circ} \mathrm{C}$ and supplemented with different concentrations of $\mathrm{NaCl}(0.17 ; 0.34$ and $0.51 \mathrm{M})$.

To evaluate the capacity to solubilize calcium phosphate, the bacteria were previously grown on YM culture media during the necessary growth time for each isolate. For inoculation on GL medium, $10 \mu \mathrm{L}$ of the culture broth was used at three equidistant points on the Petri dish. The solubilization of calcium phosphate was evaluated by measuring the diameter of the translucent halo around the bacterial colonies. For growth on media with different $\mathrm{pH}$ levels, salt concentration and incubation temperatures, the bacteria were grown on YM culture media as mentioned previously and inoculated on Petri dishes containing the modified YMA medium, whereby only one bacterium was inoculated per dish. All the evaluations were done in triplicate.

For the genotypic characterization of the bacteria, fingerprinting of the 37 isolates was carried out by means of the Box-PCR technique. For the PCR, the primer Box A1 (CTACGGCAAGGCGACGCTGACG) was used (Versalovic et al., 1994). The PCR and electrophoresis conditions adopted by Hungria et al. (2008) were followed. After electrophoresis, the gel was colored with ethyl bromide $(0.01 \% \mathrm{v} / \mathrm{v})$ and visualized under a photo-documentation system with UV light. The digitized image of the gel was evaluated using BioNumerics software (Applied Maths, Kortrijk, Belgium).

The gene sequencing of the 16S rRNA gene was carried out by the isolates AM 01 and AM 07. To amplify the 16S rDNA gene, the PCR reaction was dimensioned for a final volume of $50 \mu \mathrm{L}$ 
Table 1. Characteristics of the area where the soil samples were collected.

\begin{tabular}{|c|c|c|c|c|c|c|c|c|c|}
\hline \multirow{3}{*}{ Soil } & \multirow{3}{*}{ Characteristic of the area } & \multirow{3}{*}{ Municipality } & \multirow{3}{*}{ Coordenate } & \multirow{3}{*}{ pH } & \multicolumn{5}{|c|}{ Sorting complex } \\
\hline & & & & & $\mathrm{Al}^{+3}$ & $\mathrm{Ca}^{+2}$ & $\mathrm{Mg}^{+2}$ & \multirow{2}{*}{\multicolumn{2}{|c|}{$\frac{K^{+1} \quad P}{m g ~ d m^{-3}}$}} \\
\hline & & & & & \multicolumn{3}{|c|}{ Amolc $\mathrm{dm}^{-3}$} & & \\
\hline $\mathrm{HP}^{*}$ & $\begin{array}{l}\text { Dead tomato covering (Lycoperscon } \\
\text { esculentum L.) }\end{array}$ & ${ }^{o n}$ Seropédica-RJ & $22^{\circ} 46^{\prime} 59^{\prime \prime} \mathrm{S}, 43^{\circ} 40^{\prime} 45^{\prime \prime}$ W e $33 \mathrm{~m}$ & 6.5 & 0 & 3.6 & 1.3 & 132 & 263 \\
\hline AVA1 & Dead corn covering (Zea mays L.) & Seropédica-RJ & $22^{\circ} 46^{\prime} 59^{\prime \prime} \mathrm{S}, 43^{\circ} 40^{\prime} 45^{\prime \prime}$ w e $33 \mathrm{~m}$ & 6.3 & 0 & 1.8 & 0.8 & 104 & 50 \\
\hline AVA2 & $\begin{array}{l}\text { Dead colonial grass covering } \\
\text { (Panicummaximum) and coco-grass } \\
\text { (Cyperus rotundus } L \text {.) }\end{array}$ & ss & 22 & 5.4 & 0 & 2.5 & 0.8 & 48 & 21 \\
\hline NV & $\begin{array}{l}\text { Dead sugar cane straw covering } \\
\text { (Saccharum officinarum L) }\end{array}$ & Jaboticabal-SP & $21^{\circ} 15^{\prime} 17^{\prime \prime}$ S, 481ำ'20" W e 605 m & 6.4 & 0 & 2.8 & 0.5 & 56 & 13 \\
\hline AV & $\begin{array}{l}\text { Dead sugar cane straw covering } \\
\text { (Saccharum officinarum L) }\end{array}$ & ${ }^{g}$ Taquaritinga-SP & $21^{\circ} 24^{\prime} 22^{\prime \prime} \mathrm{S} ; 48^{\circ} 30^{\prime} 17^{\prime \prime} \mathrm{W}$ e $565 \mathrm{~m}$ & 5.4 & 0.1 & 1.4 & 0.4 & 72 & 6.4 \\
\hline LV & $\begin{array}{l}\text { Dead sugar cane straw covering } \\
\text { (Saccharum officinarum } \mathrm{L} \text { ) }\end{array}$ & ${ }^{g}$ Sertãozinho-SP & $21^{\circ} 08^{\prime} 16^{\prime \prime} \mathrm{S} 47^{\circ} 59^{\prime} 25^{\prime \prime}$ W e $579 \mathrm{~m}$ & 6.2 & 0 & 3.4 & 0.9 & 300 & 17 \\
\hline \multirow{2}{*}{\multicolumn{2}{|c|}{$\begin{array}{l}\text { Red Yellow Ultisol**} \\
\text { Haplic Planosol** }\end{array}$}} & $\mathrm{Se}$ & $22^{\circ} 46$ & 6.3 & 0.02 & 3.5 & 1.5 & 70 & 36.8 \\
\hline & & Seropédica-RJ & $22^{\circ} 46^{\prime} 59^{\prime \prime} \mathrm{S}, 43^{\circ} 40^{\prime} 45^{\prime \prime} \mathrm{W}$ e $33 \mathrm{~m}$ & 6.4 & 0.02 & 1.9 & 0.6 & 27 & 29.6 \\
\hline
\end{tabular}

${ }^{*}$ Classification according the Brazilian Soil Classification System. Haplic Planosol (HX), Red Yellow Ultisol 1 (AVA1), Red Yellow Ultis ol 2 (AVA2), Red Nitosol (NV), Red Ultisol (AV) and Red Oxisol (LV). ${ }^{* *}$ Chemical characteristics of non-autoclaved soils, used for the cultivation of two peanut varieties (BR 1 and BRS Havana) until 45 days after planting inoculated with the isolates AM 01 and AM 07.

(1X buffer, $1.75 \mathrm{mM}$ of $\mathrm{MgCl}_{2}, 0.25 \mathrm{mM}$ of each dNTP, $1 \mathrm{U}$ of Taq DNA polymerase and $0.25 \mu \mathrm{M}$ of each primer). The PCR conditions were performed conform to what was described by Leite et al. (2009) using the $\mathrm{Y} 1$ and $\mathrm{Y} 3$ primers (Young et al., 1991). The sequencing was conducted on the ABI 3730/xl platform (Applied Biosystems, Foster City, CA, USA) at Macrogene (Seoul, South Korea).

\section{Symbiotic efficiency of the isolates in pots with sterilized substrate}

Two experiments under greenhouse conditions were conducted to evaluate the nodulation capacity and the symbiotic efficiency of the isolates. Leonard jars (Vincent, 1970) containing sand and verminculite $(2: 1 \mathrm{w} / \mathrm{v})$ were used as sterile substrate. An experimental outline with a randomized block design with three replications was used. The first experiment was implemented using the genotype BR 1 and the second with the BRS Havana. For both experiments the treatment used was the inoculation of the isolated bacteria from nodules of the genotype itself. In addition, the following controls were included: a control inoculated with the SEMIA 6144 (Bradyrhizobium sp.) strain, which is used for the production of peanut inoculants in Brazil (Brasil, 2011), a nitrogen supplied control, which received $100 \mathrm{mg}$ of $\mathrm{N}$ per jar per week in the form of ammonium nitrate and an absolute control without inoculation or $\mathrm{N}$ mineral supplementation.

For the sowing, the seeds were disinfected superficially as was previously described and for the inoculation, the bacteria were grown on YM media during the adequate growth period for each isolate. At the time of planting, $1 \mathrm{~mL}$ of the culture broth with approximately $10^{9}$ of viable cells was applied to each seed. From the second week of conduction onwards, a nitrogen free nutritive solution (Norris and T'Mannetje, 1964) was applied every seven days. The plants were harvested 45 days after emergence and the following variables were analyzed: shoot dry weight (SDW), root dry weight (RDW), nodules dry weight (NDW), and the accumulation of total $\mathrm{N}$ in the shoots was also determined by the semi-micro Kjeldahl method (Liao, 1981), which is the content of $N$ in the shoots obtained by the product between the concentration and the dry mass. Analysis of variance and a comparison of means were carried out using the Scott-Knot test $(p<0.05)$ with the aid of Sisvar software (Ferreira, 2008).

\section{Symbiotic efficiency of the isolates in pots with non-sterilized soil}

An experiment was conducted in a greenhouse using nonautoclaved soil as substrate. Soil samples were collected from the superficial horizon of a Haplic Planosol and a Red Yellow Ultisol of the Integrated Agroecological Production System at the main building of Embrapa Agrobiologia in Seropédica municipality, Rio de Janeiro State. The soil samples were processed as was previously described. An experimental randomized block design following a factorial scheme of 5 (inoculation treatments) $\times 2$ (genotypes) was adopted for this experiment. The bacteria used for the inoculation treatments were the isolates $A M 01$ and AM 07 obtained from nodules of BR 1 and BRS Havana peanut genotypes respectively, and the strain SEMIA 6144 Bradyrhizobium sp. In addition to the inoculated treatments, the nitrogen supplied control treatment, with an application of $100 \mathrm{mg} \mathrm{N}$ per week per pot in the form of ammonium nitrate and the absolute control treatment, noninoculated without $\mathrm{N}$ mineral supplementation, were evaluated.

The seeds were superficially disinfected for sowing as previously described. The bacteria were grown on YM media under constant shaking during the adequate growth period for each bacterium. The 
Table 2. Number, growth time and $\mathrm{pH}$ reaction of obtained isolates of nodules from the peanut varieties (BR 1 , BRS Havana) when used as bait plant in six soil samples collected in the state of Rio de Janeiro and São Paulo.

\begin{tabular}{|c|c|c|c|c|c|c|c|c|c|c|c|c|}
\hline \multirow{3}{*}{ Solo } & \multicolumn{2}{|c|}{ Isolate obtained } & \multicolumn{4}{|c|}{ Growth time } & \multicolumn{6}{|c|}{ pH reaction } \\
\hline & \multirow{2}{*}{ BR-1 } & \multirow{2}{*}{ BRS-Havana } & \multicolumn{2}{|c|}{ BR1 } & \multicolumn{2}{|c|}{ BRS-Havana } & \multicolumn{3}{|c|}{ BR-1 } & \multicolumn{3}{|c|}{ BRS-Havana } \\
\hline & & & $\mathbf{R}$ & $\mathbf{L}$ & $\mathbf{R}$ & $\mathbf{L}$ & AC & NE & $A L$ & AC & NE & $A L$ \\
\hline HP & 4 & 3 & 2 & 2 & 3 & - & 1 & 1 & 2 & 3 & - & - \\
\hline AVA1 & 0 & 4 & - & - & 4 & - & - & - & - & 4 & - & - \\
\hline AVA2 & 3 & 5 & 3 & - & 5 & - & 3 & - & - & 4 & 1 & - \\
\hline NV & 4 & 4 & 3 & 1 & 4 & - & 1 & 2 & 1 & 2 & 2 & - \\
\hline AV & 2 & 3 & 2 & - & 3 & - & 1 & 1 & - & 3 & - & - \\
\hline LV & 3 & 2 & 3 & - & 2 & - & 3 & - & - & 2 & - & - \\
\hline Total & 16 & 21 & 13 & 3 & 21 & - & 9 & 4 & 3 & 18 & 3 & - \\
\hline
\end{tabular}

$\mathrm{R}$ : rapid growth; L: slow growth. $\mathrm{AC}$ : reaction of acid $\mathrm{pH}$; $\mathrm{NE}$ : reaction of neutral $\mathrm{pH} ; \mathrm{AL}$ : reaction of alkaline $\mathrm{pH}$.

inoculation was carried out at the moment of sowing, applying $1 \mathrm{~mL}$ of culture broth with approximately $10^{9}$ colony forming unities. The soil humidity was maintained close to the field capacity, using drinkable water, passed through an activated carbon filter. The harvest was carried out after 45 days. The shoots were separated from the roots during harvesting. All the components were accommodated in a forced ventilation chamber at $65^{\circ} \mathrm{C}$ until the constant weight to determine the SDW, RDW and the NDW and the accumulation of total $\mathrm{N}$ of the aerial part as described above. The data were submitted for analysis of variance. The comparison of means test used was the t-test (LSD) at $5 \%$ of probability, using the SISVAR program (Ferreira, 2008).

\section{RESULTS}

\section{Phenotypic and genetic variability of the isolates}

From all bacteria obtained, 37 bacteria that re-nodulated the original host were obtained. Among the nodulating isolates of the genotype BR 1, four and three were obtained from the Planosol and from the Red Yellow Ultisol 2, respectively, soils that were collected in the state of Rio de Janeiro. Four, two and three of the soils that were collected in the state of São Paulo were obtained from plants grown in samples of Red Nitosol, Yellow Ultisol and Red Oxisol, respectively (Table 2). Among the 21 bacteria that nodulated, the genotype BRS Havana, three, four and five were isolated from plants grown in samples of Planosol, Red Yellow Ultisol 1, Red Yellow Ultisol 2, collected in the state of Rio de Janeiro. The bacteria isolated from plants grown in soil samples in the state of São Paulo, four, three and two were obtained from Red Nitosol, Red Ultisol and Red Oxisol, respecttively. Among the 37 obtained isolates, 34 were classified as fast growing, and only three as slow growing. Analyzing the $\mathrm{pH}$ reaction of the culture media, 27 isolates showed the capacity to acidify the culture medium, seven did not alter the $\mathrm{pH}$ of the medium and three alkalinized the YMA medium.

In the similarity dendrogram, based on fingerprinting the isolates using the Box-PCR technique, it was possible to observe eight distinct clusters with $50 \%$ similarity among themselves (Figure 1). Cluster I gathered four isolates of which two came from the same soil in the state of São Paulo and the others were collected in distinct states. Clusters II, IV and V clustered only two isolates. Cluster III was formed only by one isolate. The two isolates of cluster IV were isolated from the same soil in the state of São Paulo while the two representatives of groups II and V were collected from different states. Two main clusters (VI and VII) can be observed in the dendrogram. Cluster VI included 13 isolates, which were two bacteria obtained from nodules of the genotype BRS Havana from the Haplic Planosol in the state of Rio de Janeiro and three from the same peanut genotype in Red Nitosol from the state of São Paulo. Among the other bacteria of this group, two isolates were collected from Red Oxisol and five from Red Nitosol, both from the state of São Paulo. Cluster VII joined eight isolates besides the SEMIA 6144 reference strain. In this group, $50 \%$ of the isolates were collected from each of the studied states. Cluster VIII included five isolates, four of which were isolated from soil samples in the state of Rio de Janeiro.

\section{Symbiotic performance of the isolates in sterilized subtrate}

In the two trials that were carried out in sterilized substrate, a pre-selection was made based on the symbiotic efficiency of the isolates obtained in this study. Two isolates (AM 01 and AM 03) that were obtained from the cultivar BR 1 stood out compared to the others, once the plants inoculated with these bacteria showed nodule weight and dry roots similar to what was observed for the plants inoculated with the SEMIA 6144 strain (Table 4). The inoculation treatment with these isolates resulted in plants with a shoot dry weight which was larger than what was observed for plants that received mineral $\mathrm{N}$ 


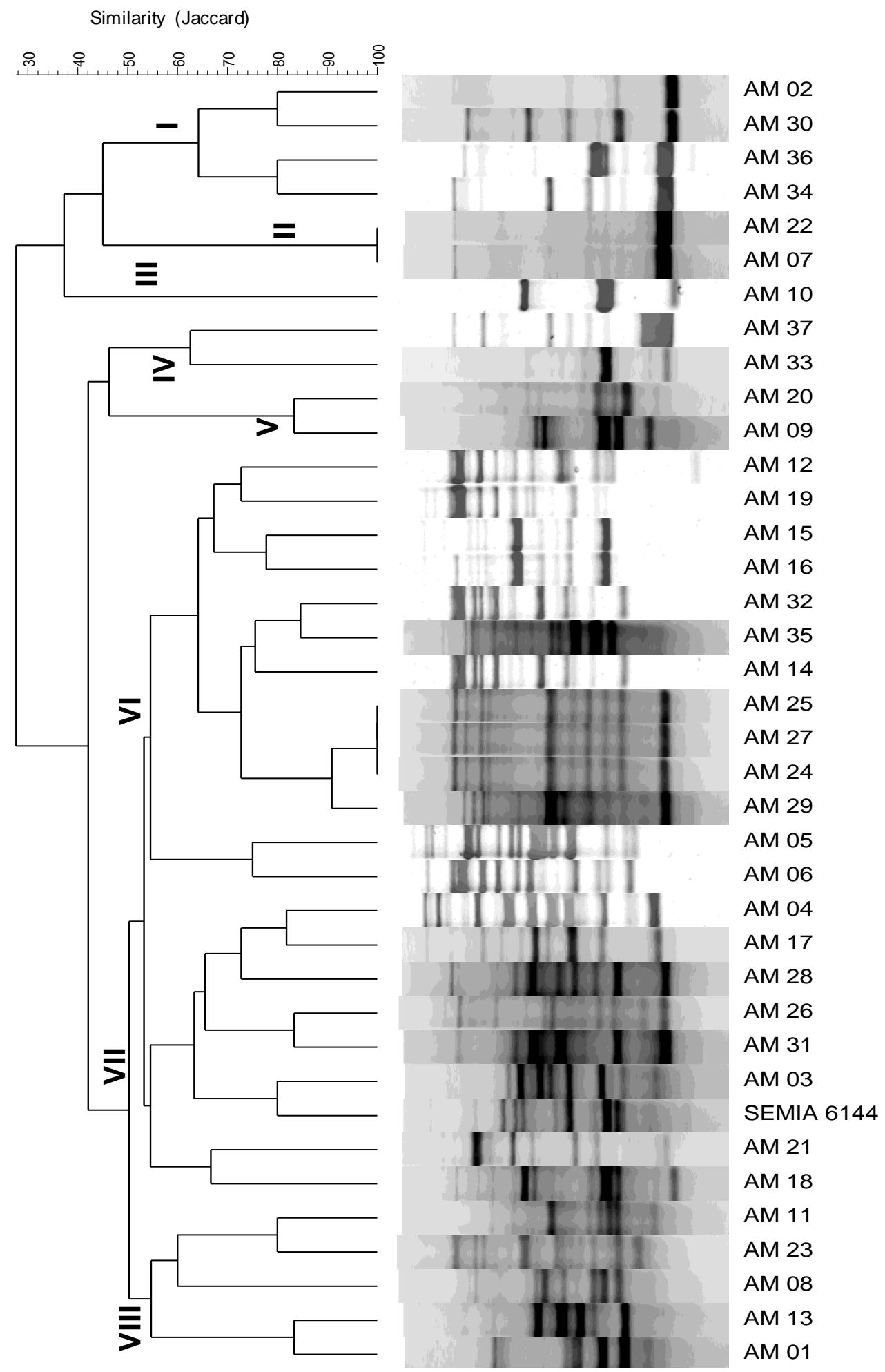

Figure 1. Similarity dendrogram among the bacterial isolates obtained from nodules of two peanut varieties (BR-1 and BRS Havana) and the officially recommended strain for the peanut (SEMIA 6144) in Brazil.

supplements, yet smaller than what was observed for plants inoculated with the SEMIA 6144 strain. The plants inoculated with the isolate AM 01 showed a larger total $\mathrm{N}$ in the shoot than the treatment plants that were 


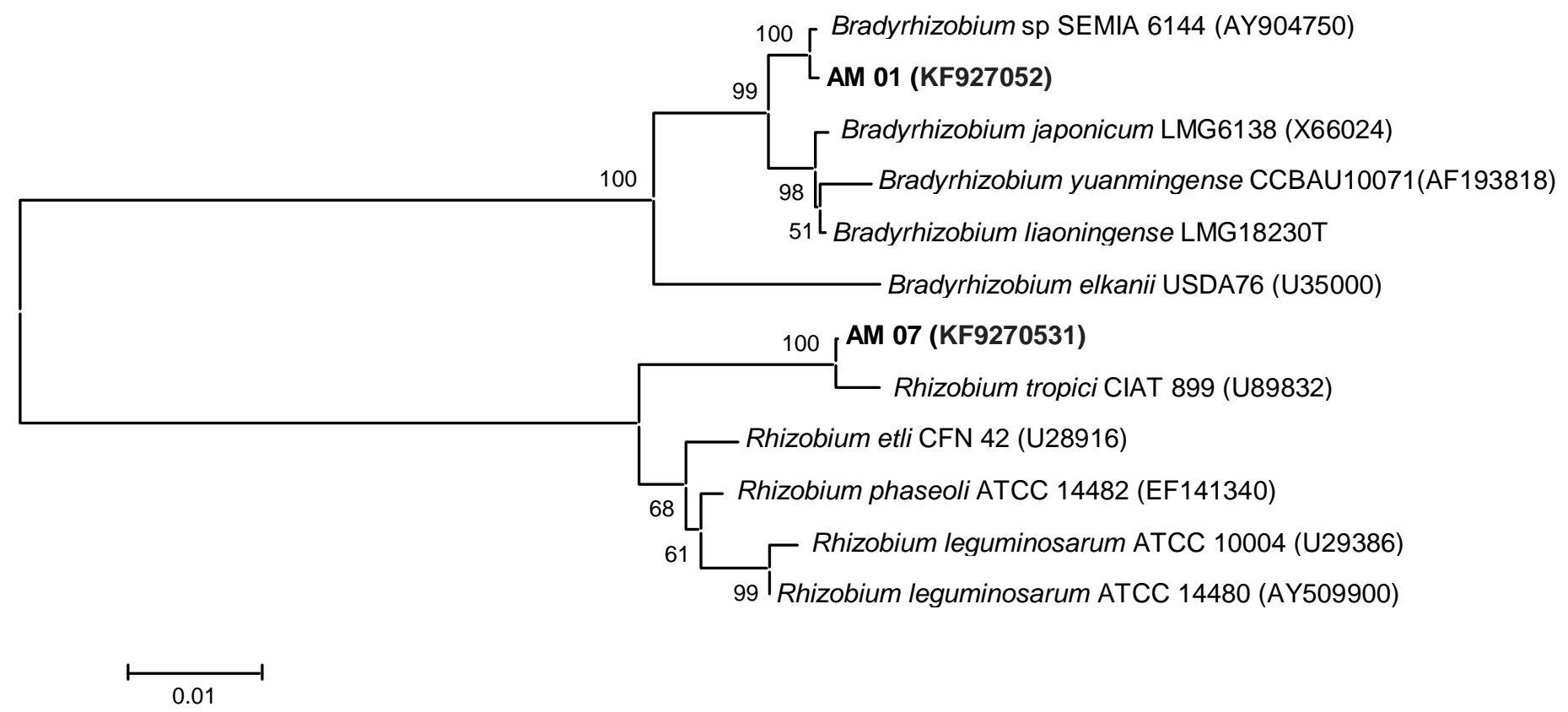

Figure 2. Phylogenetic tree reconstructed from the 16S rRNA gene sequences of the bacteria AM 01 and AM 07 which were isolated from nodules of the varieties BR 1 and BRS Havana, respectively, using the Neighbor-Joining method, with distances calculated by the JukesCantor method. The values of each branch represent 1000 bootstrap replications.

supplemented with $\mathrm{N}$ mineral and it was the same for the plants inoculated with the SEMIA 6144 strain. The plants inoculated with the isolate AM 03 showed a higher total N than the $\mathrm{N}$ supplemented control and a lower total $\mathrm{N}$ than the plants inoculated with the SEMIA 6144 strain.

In the experiment using the genotype BRS Havana in sterilized substrate, it was possible to observe that the plants inoculated with AM 07, AM 11, AM 15, AM 24 and AM 32 showed a larger nodule dry weight when compared to the treatment inoculated with the SEMIA 6144 strain (Table 5). It was also possible to observe that plants of the variety BRS Havana inoculated with the isolates AM 07, AM 10, AM 15, AM 31, AM 32 e AM 36 showed a larger dry mass of the aerial part than the plants that received mineral nitrogen. However, in none of the inoculated treatments with the isolates obtained in this study did the plants show dry mass of the aerial part or total $\mathrm{N}$ equal to what was observed for plants inoculated with the SEMIA 6144 strain.

\section{The 16S rRNA sequence analysis}

The 16S rDNA sequence analysis of the isolates AM 01 and AM 07, isolates which show better symbiotic performance, made it possible to verify that the isolates showed similarities with distinct genera of rhizobia (Figure 2). The isolate AM 01, which shows slow growth and the capacity to alkalinize the medium culture (belonging to group eight according to the Box-PCR technique) showed $99.85 \%$ of identity with the SEMIA 6144 strain of Bradyrhizobium sp. On the other hand, the fast growing isolate that acidify the culture medium, AM 07 , was belonged to group 2 in the similarity dendrogram using the Box-PCR technique, showed an identity of 99.62\% with the CIAT $899^{1}$ of Rhizobium tropici. The sequences of these two isolates were deposited to the GenBank database with accession numbers KF927052 (AM01) and KF9270531 (AM07).

\section{Solubilization phosphate and effect of $\mathrm{pH}, \mathrm{NaCl}$ and temperature on AM 01 and AM 07}

The isolates AM 01, AM 07 and the SEMIA 6144 strain grew on the YMA media under all tested $\mathrm{pH}$ levels $(4 ; 5$; 7,9 e 11) and only isolate AM 07 was capable of solubilizing the calcium phosphate on GL media when glucose was used as a carbon source, in spite of being able to also grow on GL media with mannitol without showing the capacity to solubilize the phosphate (Table 3). As for growth at different incubation temperatures, the three tested bacteria grew until $39^{\circ} \mathrm{C}$ but were not able to grew when incubated at $45^{\circ} \mathrm{C}$ (Table 3 ). To evaluate the growth capacity of the bacteria on culture media supplemented with different concentrations of $\mathrm{NaCl}$, the isolate AM 01 and the SEMIA 6144 strain showed growth only in the control treatment, without salt supplements. However, the isolate AM 07 was capable to grow on the media supplemented with up to $0.34 \mathrm{M}$ de $\mathrm{NaCl}$. 
Table 3. Evaluation of growth of the isolates AM 01 and AM $07 \mathrm{in} \mathrm{pH}$ ranges, of temperature, salinity and its ability to solubilize calcium phosphate.

\begin{tabular}{|c|c|c|c|c|c|c|c|c|c|c|c|c|c|c|c|c|c|c|c|c|}
\hline \multirow{3}{*}{ Bacteria } & \multirow{2}{*}{\multicolumn{5}{|c|}{$\mathrm{pH}$}} & \multicolumn{9}{|c|}{ Solubilization of calcium phosphate } & \multicolumn{3}{|c|}{ Temperature } & \multicolumn{3}{|c|}{ Salinity } \\
\hline & & & & & & \multicolumn{4}{|c|}{ Mannitol } & \multicolumn{5}{|c|}{ Glucose } & \multirow[b]{2}{*}{$25 \circ \mathrm{C}$} & \multirow[b]{2}{*}{$39^{\circ} \mathrm{C}$} & \multirow[b]{2}{*}{$45^{\circ} \mathrm{C}$} & \multirow[b]{2}{*}{$1 \%$} & \multirow[b]{2}{*}{$2 \%$} & \multirow[b]{2}{*}{$3 \%$} \\
\hline & 4 & 5 & 7 & 9 & 11 & $3^{\star}$ & 6 & 9 & 12 & 3 & 6 & 9 & 12 & SI & & & & & & \\
\hline SEMIA 6144 & + & + & + & + & + & - & - & - & - & - & - & - & - & - & + & + & - & - & - & - \\
\hline AM 01 & + & + & + & + & + & - & - & - & - & - & - & - & - & - & + & + & - & - & - & - \\
\hline AM 07 & + & + & + & + & + & + & + & + & + & 1.43 & 1.33 & 1.33 & 1.31 & low & + & + & - & + & + & - \\
\hline
\end{tabular}

(+) Bacterial growth was observed. (-) Growth of the isolate was not observed. SI = Solubilization index. * Days after inoculation

Table 4. Dry mass of the aerial part, of the nodules, and accumulation of nitrogen in the aerial part of the peanut variety BR 1 inoculated with different rhizobial isolates, SEMIA 6144 reference strain, nitrogen supplied control (with $\mathrm{N}$ and without inoculation) and absolute control (without $\mathrm{N}$ and without inoculation).

\begin{tabular}{lcccc}
\hline \multirow{2}{*}{ Treatment } & $\begin{array}{c}\text { Dry shoot } \\
\text { weight }\end{array}$ & $\begin{array}{c}\text { Dry root } \\
\text { weight }\end{array}$ & $\begin{array}{c}\text { Dry nodule } \\
\text { weight }\end{array}$ & $\begin{array}{c}\text { Total N of the } \\
\text { shoot }\end{array}$ \\
\cline { 2 - 6 } & \multicolumn{2}{c}{ g plant $^{-1}$} & \multicolumn{2}{c}{ mg plant $^{-1}$} \\
\hline AM 02 & $1.5^{\mathrm{e}}$ & $0.6^{\mathrm{a}}$ & $90^{\mathrm{a}}$ & $32.9^{\mathrm{c}}$ \\
AM 04 & $1.7^{\mathrm{e}}$ & $0.5^{\mathrm{a}}$ & $100^{\mathrm{a}}$ & $39.2^{\mathrm{c}}$ \\
AM 14 & $1.3^{\mathrm{e}}$ & $0.5^{\mathrm{a}}$ & $40^{\mathrm{b}}$ & $21.2^{\mathrm{c}}$ \\
AM 12 & $1.6^{\mathrm{e}}$ & $0.8^{\mathrm{a}}$ & $90^{\mathrm{a}}$ & $22.3^{\mathrm{c}}$ \\
AM 13 & $1.5^{\mathrm{e}}$ & $0.5^{\mathrm{a}}$ & $10^{\mathrm{b}}$ & $19.6^{\mathrm{c}}$ \\
AM 20 & $1.3^{\mathrm{e}}$ & $0.3^{\mathrm{b}}$ & $70^{\mathrm{a}}$ & $22.9^{\mathrm{c}}$ \\
AM 21 & $1.1^{\mathrm{f}}$ & $0.2^{\mathrm{b}}$ & $50^{\mathrm{a}}$ & $16.0^{\mathrm{c}}$ \\
AM 22 & $1.1^{\mathrm{f}}$ & $0.5^{\mathrm{a}}$ & $100^{\mathrm{a}}$ & $14.0^{\mathrm{c}}$ \\
AM 23 & $1.3^{\mathrm{e}}$ & $0.5^{\mathrm{a}}$ & $90^{\mathrm{a}}$ & $16.4^{\mathrm{c}}$ \\
AM 28 & $1.0^{\mathrm{f}}$ & $0.7^{\mathrm{a}}$ & $70^{\mathrm{a}}$ & $11.3^{\mathrm{c}}$ \\
AM 29 & $1.5^{\mathrm{e}}$ & $0.7^{\mathrm{a}}$ & $70^{\mathrm{a}}$ & $18.1^{\mathrm{c}}$ \\
AM 33 & $1.5^{\mathrm{e}}$ & $0.4^{\mathrm{b}}$ & $90^{\mathrm{a}}$ & $28.3^{\mathrm{c}}$ \\
AM 34 & $1.1^{\mathrm{f}}$ & $0.3^{\mathrm{b}}$ & $100^{\mathrm{a}}$ & $19.7^{\mathrm{c}}$ \\
AM 35 & $0.8^{\mathrm{f}}$ & $0.1^{\mathrm{b}}$ & $70^{\mathrm{a}}$ & $25.5^{\mathrm{c}}$ \\
AM 03 & $3.6^{\mathrm{b}}$ & $0.6^{\mathrm{a}}$ & $100^{\mathrm{a}}$ & $109.3^{\mathrm{b}}$ \\
AM 01 & $3.1^{\mathrm{c}}$ & $0.5^{\mathrm{a}}$ & $100^{\mathrm{a}}$ & $144.3^{\mathrm{a}}$ \\
SEMIA 6144 & $4.5^{\mathrm{a}}$ & $0.7^{\mathrm{a}}$ & $110^{\mathrm{a}}$ & $158.9^{\mathrm{a}}$ \\
N supplied control & $2.7^{\mathrm{d}}$ & $0.8^{\mathrm{a}}$ & $0^{\mathrm{b}}$ & $106.1^{\mathrm{b}}$ \\
Absolute control & $1.2^{\mathrm{f}}$ & $0.3^{\mathrm{b}}$ & $0^{\mathrm{b}}$ & $17.3^{\mathrm{c}}$ \\
CV (\%) & 12.5 & 35.9 & 28.4 & 31.2 \\
\hline V & & $35.5^{\mathrm{a}}$ &
\end{tabular}

Values are means of three repetitions. Values followed by the same letter do not differ from the ScottKnott test at $5 \%$.

\section{Symbiotic performance of the isolates in non- autoclaved soil substrate}

For the experiment that was carried out using nonautoclaved soil as substrate, it was possible to observe that the inoculation of the three bacteria (AM 01, AM 07 which showed better results in previous tests - and the SEMIA 6144 strain) stimulated the nodulation in both genotypes when cultivated in samples of Red Yellow Ultisol (Table 6). In this same soil, plants of the geno- types BR 1, inoculated with the isolate AM 01, showed a higher dry mass of the aerial part than what was observed in the absolute control treatments and SEMIA 6144 , and the values were the same as those observed in the $\mathrm{N}$ fertilized control treatments and AM 07. In the Haplic Planosol, plants of the variety BR1, inoculated with the isolates AM 01 and AM 07, showed a dry weight of the shoot equal to what was observed in the absolute control treatments and SEMIA 6144 where the mass of the plants inoculated with AM 01 was also equal to the 
Table 5. Dry mass of the aerial part, of the root, of the nodules and nitrogen accumulation in the aerial part of de peanut variety BRS Havana, inoculated with different rhizobial isolates, SEMIA 6144 reference strain, nitrogenized control (with and without inoculation) and absolute control (without $\mathrm{N}$ and without inoculation).

\begin{tabular}{lcccc}
\hline Treatment & $\begin{array}{c}\text { Dry shoot } \\
\text { weight }\end{array}$ & $\begin{array}{c}\text { Dry root } \\
\text { weight }\end{array}$ & $\begin{array}{c}\text { Dry nodule } \\
\text { weight }\end{array}$ & $\begin{array}{c}\text { Total N of the } \\
\text { shoot }\end{array}$ \\
\cline { 2 - 5 } & \multicolumn{2}{c}{ g plant $^{-1}$} & & \multicolumn{2}{c}{ mg plant $^{-1}$} \\
\hline AM 08 & $1.3^{\mathrm{c}}$ & $0.7^{\mathrm{a}}$ & $97^{\mathrm{b}}$ & $15.2^{\mathrm{b}}$ \\
AM 06 & $1.2^{\mathrm{c}}$ & $0.6^{\mathrm{a}}$ & $100^{\mathrm{b}}$ & $11.1^{\mathrm{b}}$ \\
AM 05 & $1.2^{\mathrm{c}}$ & $0.6^{\mathrm{a}}$ & $80^{\mathrm{b}}$ & $11.6^{\mathrm{b}}$ \\
AM 37 & $0.8^{\mathrm{c}}$ & $0.3^{\mathrm{b}}$ & $96^{\mathrm{b}}$ & $13.2^{\mathrm{b}}$ \\
AM 09 & $0.9^{\mathrm{c}}$ & $0.3^{\mathrm{b}}$ & $79^{\mathrm{b}}$ & $11.0^{\mathrm{b}}$ \\
AM 11 & $1.2^{\mathrm{c}}$ & $0.6^{\mathrm{a}}$ & $103^{\mathrm{a}}$ & $14.9^{\mathrm{b}}$ \\
AM 10 & $1.6^{\mathrm{b}}$ & $0.7^{\mathrm{a}}$ & $68^{\mathrm{b}}$ & $21.4^{\mathrm{b}}$ \\
AM 15 & $1.7^{\mathrm{b}}$ & $0.7^{\mathrm{a}}$ & $117^{\mathrm{a}}$ & $27.2^{\mathrm{b}}$ \\
AM 17 & $1.2^{\mathrm{c}}$ & $0.6^{\mathrm{a}}$ & $95^{\mathrm{b}}$ & $18.4^{\mathrm{b}}$ \\
AM 18 & $1.0^{\mathrm{c}}$ & $0.4^{\mathrm{b}}$ & $80^{\mathrm{b}}$ & $15.6^{\mathrm{b}}$ \\
AM 16 & $1.2^{\mathrm{c}}$ & $0.6^{\mathrm{a}}$ & $73^{\mathrm{b}}$ & $14.6^{\mathrm{b}}$ \\
AM 19 & $1.4^{\mathrm{c}}$ & $0.8^{\mathrm{a}}$ & $52^{\mathrm{c}}$ & $28.3^{\mathrm{b}}$ \\
AM 25 & $1.0^{\mathrm{c}}$ & $0.4^{\mathrm{b}}$ & $85^{\mathrm{b}}$ & $15.7^{\mathrm{b}}$ \\
AM 24 & $1.5^{\mathrm{c}}$ & $0.6^{\mathrm{a}}$ & $140^{\mathrm{a}}$ & $20.4^{\mathrm{b}}$ \\
AM 26 & $1.2^{\mathrm{c}}$ & $0.5^{\mathrm{b}}$ & $80^{\mathrm{b}}$ & $17.8^{\mathrm{b}}$ \\
AM 27 & $0.9^{\mathrm{c}}$ & $0.3^{\mathrm{b}}$ & $75^{\mathrm{b}}$ & $12.2^{\mathrm{b}}$ \\
AM 30 & $1.3^{\mathrm{c}}$ & $0.7^{\mathrm{a}}$ & $68^{\mathrm{b}}$ & $19.2^{\mathrm{b}}$ \\
AM 31 & $1.9^{\mathrm{b}}$ & $0.6^{\mathrm{a}}$ & $100^{\mathrm{b}}$ & $26.2^{\mathrm{b}}$ \\
AM 32 & $1.7^{\mathrm{b}}$ & $0.5^{\mathrm{b}}$ & $111^{\mathrm{a}}$ & $18.3^{\mathrm{b}}$ \\
AM 36 & $1.8^{\mathrm{b}}$ & $0.8^{\mathrm{a}}$ & $92^{\mathrm{b}}$ & $21.5^{\mathrm{b}}$ \\
AM 07 & $1.8^{\mathrm{b}}$ & $0.6^{\mathrm{a}}$ & $136^{\mathrm{a}}$ & $37.0^{\mathrm{b}}$ \\
SEMIA 6144 & $2.9^{\mathrm{a}}$ & $0.4^{\mathrm{b}}$ & $82^{\mathrm{b}}$ & $106.0^{\mathrm{a}}$ \\
N supplied control & $0.7^{\mathrm{c}}$ & $0.4^{\mathrm{b}}$ & $0 \mathrm{~d}$ & $24.2^{\mathrm{b}}$ \\
Absolute control & $1.1^{\mathrm{c}}$ & $0.8^{\mathrm{a}}$ & $0 \mathrm{~d}$ & $13.0^{\mathrm{b}}$ \\
CV (\%) & 17.9 & 28.1 & 29.9 & 25.2 \\
\hline V & 17.9 & & & \\
\hline
\end{tabular}

Values are means of three repetitions. Values followed by the same letter do not differ from the Scott-Knott test at $5 \%$.

nitrogenized control.

The inoculation of both isolated bacteria in this study in the variety BRS Havana did not positively influence the production of the aerial part, which was inferior to the $\mathrm{N}$ fertilized control treatment, however, equal to the treatments inoculated with SEMIA 6144 strain. In the Red Yellow Ultisol, which has better fertility characteristics than the Haplic Planosol, plants of the variety BR 1 inoculated with the isolates AM 01 and AM 07 showed a higher $\mathrm{N}$ content than what was observed in the absolute control treatment, SEMIA 6144 and $\mathrm{N}$ fertilized traetments.

In this same soil, plants of the genotype BRS Havana, inoculated with the same isolates, showed an $\mathrm{N}$ content equal to the absolute control treatments and SEMIA 6144 with an $\mathrm{N}$ content of the plants inoculated with the isolate AM 01 that was also similar to that of the $\mathrm{N}$ supplied control. In the Haplic Planosol, which has a fertility condition lower to the red yellow ultisol, plants belonging to the variety BR 1, inoculated with isolates AM 01 and AM 07, showed an $\mathrm{N}$ content equal to that of the absolute control treatments and SEMIA 6144 with an N content of the plants inoculated with the isolate AM 01 that was also similar to the $\mathrm{N}$ supplemented control. In the same soil, plants of the genotype BRS Havana did not respond to any of the treatments. The isolate AM 01 stimulated the development of the root system of the variety BRS Havana in both soils used.

In the plants inoculated with the isolate AM 01, the dry root mass was similar to that of the $\mathrm{N}$ fertilized control treatments and inoculation with the SEMIA 6144 strain, to plants that grew in samples of the Red Yellow Ultisol and higher when the same variety was grown in Haplic Planosol. The same isolate still stimulated the development of the root system of the variety BR1, but only when the plants were cultivated in Haplic Planosol. The isolate 
Table 6. Dry mass of the root, of the aerial part, of the nodules and nitrogen accumulation in the aerial part of the peanut varieties BR 1 and BRS Havana, grown in pots with two distinct types of soil and inoculated with rhizobial isolates or recommended strain in the absence our presence of mineral nitrogen.

\begin{tabular}{|c|c|c|c|c|c|}
\hline \multirow{2}{*}{ Isolate } & \multicolumn{2}{|c|}{ Red Yellow Ultisol } & \multicolumn{2}{|c|}{ Planosol } & \multirow{2}{*}{ Mean } \\
\hline & BR-1 & BRS-Havana & BR-1 & BRS-Havana & \\
\hline \multicolumn{6}{|c|}{ Root dry weight (g planta ${ }^{-1}$ ) } \\
\hline Absolute control & $1.8^{\mathrm{abA}}$ & $1.5^{\mathrm{bA}}$ & $3.8^{\mathrm{abA}}$ & $2.5^{\mathrm{abB}}$ & $2.4^{\mathrm{c}}$ \\
\hline N supplied control & $2.5^{\mathrm{abA}}$ & $3.1^{\mathrm{aA}}$ & $4.2^{\mathrm{aA}}$ & $3.4 b^{\mathrm{A}}$ & $3.3^{\mathrm{a}}$ \\
\hline SEMIA 6144 & $2.1^{\mathrm{abA}}$ & $2.7^{\mathrm{aA}}$ & $2.9^{\mathrm{bcA}}$ & $2.1^{\mathrm{cA}}$ & $2.5^{\mathrm{bc}}$ \\
\hline AM 07 & $2.8^{\mathrm{aA}}$ & $1.4^{\mathrm{bB}}$ & $2.4^{\mathrm{cA}}$ & $2.8^{\mathrm{abA}}$ & $2.4^{\mathrm{C}}$ \\
\hline AM 01 & $1.7^{\mathrm{bA}}$ & $2.3^{\mathrm{abA}}$ & $3.0^{\mathrm{abcB}}$ & $4.9 \mathrm{a}^{\mathrm{A}}$ & $3.0^{\mathrm{ab}}$ \\
\hline CV (\%) & & & 25.45 & & \\
\hline \multicolumn{6}{|c|}{ Nodule dry weight $\left(\mathrm{mg} \mathrm{plant}^{-1}\right)$} \\
\hline Absolute control & 160 & 190 & 130 & 100 & $145^{\mathrm{b}}$ \\
\hline N supplied control & 160 & 140 & 40 & 40 & $95^{\mathrm{c}}$ \\
\hline SEMIA 6144 & 250 & 200 & 150 & 120 & $180^{\mathrm{ab}}$ \\
\hline AM 07 & 290 & 210 & 160 & 110 & $193^{a}$ \\
\hline AM 01 & 360 & 260 & 120 & 140 & $220^{a}$ \\
\hline CV (\%) & & & 26.35 & & \\
\hline \multicolumn{6}{|c|}{ Shoot dry weight (g plant ${ }^{-1}$ ) } \\
\hline Absolute control & $14.7^{\mathrm{cA}}$ & $12.3^{\mathrm{cA}}$ & $10.2^{\mathrm{abA}}$ & $8.4^{\mathrm{aA}}$ & $11.4^{\mathrm{c}}$ \\
\hline $\mathrm{N}$ supplied control & $21.0^{\mathrm{aA}}$ & $19.6^{\mathrm{aA}}$ & $11.6^{\mathrm{aA}}$ & $10.2^{\mathrm{aA}}$ & $15.6^{\mathrm{a}}$ \\
\hline SEMIA 6144 & $14.7^{\mathrm{CA}}$ & $17.7^{\mathrm{abA}}$ & $9.3^{\mathrm{abA}}$ & $8.9^{\mathrm{aA}}$ & $12.7^{b c}$ \\
\hline AM 07 & $17.7^{\mathrm{bcA}}$ & $14.7^{\mathrm{bcA}}$ & $7.3^{\mathrm{bA}}$ & $9.5^{\mathrm{aA}}$ & $12.3^{\mathrm{bc}}$ \\
\hline AM 01 & $19.0^{\mathrm{abA}}$ & $14.5^{\mathrm{bcB}}$ & $8.5^{\mathrm{abA}}$ & $10.3^{\mathrm{aA}}$ & $13.1^{\mathrm{b}}$ \\
\hline CV (\%) & & & 14.16 & & \\
\hline \multicolumn{6}{|c|}{ Total $\mathrm{N}$ of the shoot (mg plant ${ }^{-1}$ ) } \\
\hline Absolute control & $408^{\mathrm{bA}}$ & $409^{\mathrm{abA}}$ & $265^{\mathrm{abA}}$ & $211^{\mathrm{aA}}$ & $323^{b}$ \\
\hline N supplied control & $473^{\mathrm{bA}}$ & $545^{\mathrm{aA}}$ & $354^{\mathrm{aA}}$ & $332^{\mathrm{aA}}$ & $426^{\mathrm{a}}$ \\
\hline SEMIA 6144 & $482^{\mathrm{bA}}$ & $534^{\mathrm{abA}}$ & $225^{\mathrm{abA}}$ & $236^{\mathrm{aA}}$ & $369^{\mathrm{ab}}$ \\
\hline AM 07 & $512^{\mathrm{abA}}$ & $400^{\mathrm{bA}}$ & $197^{\mathrm{bA}}$ & $246^{\mathrm{aA}}$ & $339^{\mathrm{b}}$ \\
\hline AM 01 & $628^{\mathrm{aA}}$ & $450^{\mathrm{abB}}$ & $214^{\mathrm{abA}}$ & $252^{\mathrm{aA}}$ & $384^{\mathrm{ab}}$ \\
\hline CV (\%) & & & 22.89 & & \\
\hline
\end{tabular}

The same letter, lower case in the column and upper case on the line (among genotypes on the same soil) do not differ statistically among themselves, by the t-test (LSD) at a $5 \%$ level of probability. Means without a letter were not significant by the $\mathrm{F}$-test at $5 \%$ probability.

AM 07 did not positively influence the development of the root system of none of the varieties in both the soils.

\section{DISCUSSION}

Fast-growing bacteria able to acidify the culture medium have been isolated from peanut nodules (Santos et al., 2005; Borges et al., 2007; Lyra et al., 2013) and from other tropical legumes such as velvet beans (Lima et al., 2012), the cowpea (Leite et al., 2009), the pigeonpea (Fernandes Júnior et al., 2012) and the yam bean (Freitas et al., 2007) in studies carried out in Brazil. Apart from nodulating abundantly with slow-growing bacteria, commonly called as cowpea miscellany or tropical Bradyrhizobium (Thies et al., 1991), the peanut is considered a species capable of forming nodules in association with a wide range rhizobia showing great diversity (Borges et al., 2007), including the strains of fast growth (Santos et al., 2005; Taurian et al., 2006; Lyra et al., 2013). In this study, the majority of the bacteria showed rapid growth and acidification of the culture media.

In this study, the non-solubilization of calcium phosphate by Bradyrhizobium sp. is possibly related to the increase of the $\mathrm{pH}$, which is a characteristic of bacteria of this genus. In spite of there are bradyrhizobia with able to 
solubilize calcium phosphate "in vitro" (Marra et al., 2011) a mechanism that better explains this characteristic is the exudation of organic acids (Marra et al., 2012), which would probably be rare for bacteria with a reaction to alkaline $\mathrm{pH}$ and does not occur in the strain AM 01 that showed a high similarity to Bradyrhizobium sp. In spite of a large quantity of rhizobial isolates being able to solubilize insoluble phosphates, the low efficiency of solubilization by this group of bacteria has been reported in the literature (Hara and Oliveira, 2005; Chagas Júnior, 2010; Marra et al., 2012).

Abiotic factors such as temperature, $\mathrm{pH}$ and salinity interfere positively or negatively with the growth of the rhizobia (Nóbrega et al., 2004; Xavier et al., 2007; Fernandes Júnior et al., 2012). The tolerance of the isolate AM 07 to saline stress was higher than what was observed for the other two evaluated bacteria, which may be related to the high production of mucus by this isolate, as available results in the literature report that, among other mechanisms, the production of exopolysaccharides may be related to the survival of rhizobial isolates and various potentially stressing environmental factors (Bushby and Marshall, 1977; Fernandes Júnior et al., 2010; Bomfeti et al., 2011).

The molecular analysis of the evaluated rhizobial isolates showed that there was a great genetic variability among the evaluated bacteria. It was found that many bacteria have less than $40 \%$ similarity. The slow growing strains also showed low similarity with the SEMIA 6144 strain, which indicates that, apart from sharing phenotypic characteristics, they are isolates that differs genetically.

The variability of rhizobia and other tropical rhizobacteria has been evaluated by the Box-PCR technique and the current results of this study corroborate the large genetic variability of the bacteria associated with the crop species (Kaschuk et al., 2006; Freitas et al., 2007; Stocco et al., 2008; Lyra et al., 2013) and native plant species (Fernandes Júnior et al., 2013). Recently, Lyra et al. (2013) applying the Box-PCR technique to assess the diversity of peanut rhizobia from Brazilian northeast region also showed less than $50 \%$ of similarity among the 22 bacteria evaluated. There are no available data in the literature where the genetic variability of peanut rhizobia from Brazilian southeast region was evaluated by the Box-PCR technique.

The almost complete 16S rDNA gene sequencing of the bacteria with better symbiotic efficiency in the original variety showed an increased proximity with Bradyrhizobium sp., the SEMIA 6144 strain and Rhizobium tropici CIAT $899^{\top}$. The genetic similarity of the isolate AM 01 with the recommended strain for peanut culture in Brazil may be related to the high symbiotic performance of this isolate. The two classic genera of rhizobia identified in this study are widely distributed in soils in South-America and their capacity to nodulate the peanut, including the isolate of the Rhizobium genus, has already been demonstrated (Taurian et al., 2006).
The nodulating bacteria of peanuts here studied show a large variability with respect to their symbiotic efficiency. One isolate from BR 1 genotype showed increased efficiency and did not differ statistically from SEMIA 6144 reference strain and was superior to the $\mathrm{N}$ supplied control in regarding the nitrogen accumulated in the aerial part and nodulation parameters. None of the isolates of the variety BRS Havana showed a performance equal to the SEMIA 6144 strain. The variability in symbiotic efficiency among isolates has been noted while evaluating rhizobia cultures of various species of tropical legumes (Florentino et al., 2010; Lima et al., 2012). The variability in the symbiotic capacity of the rhizobial culture collections has been in agreement with the biodiversity observed in these micro-organisms. Therefore, symbiotic efficiency of rhizobia is very dependent, among other factors, on various bacterial genes. It is expected that bacteria with a large genetic variability, such as the ones evaluated in this study, show a variable symbiotic efficiency.

The genotype BR 1 was more responsive to the inoculation of the rhizobial isolates in this study compared to the genotype BRS Havana, both in the trials in sterile substrate and in the soil. However, when analyzing the treatments inoculated with the reference strain, the effectiveness of inoculation was larger for the genotype BRS Havana. The variability in the response of these varieties to inoculation with the recommended SEMIA 6144 strain has already been demonstrated in a recent study where the variety BRS Havana showed a larger effectiveness when compared to the variety BR 1 when inoculated in a sandy loam soil (Melo, 2013). This way, strain selection studies can be conducted with a greater emphasis on inoculation of the variety BR 1 because the variety BRS Havana establishes a more efficient association with the currently recommended strain.

In the present study, a large genetic and phenotypic variability can be observed in rhizobia isolated from the soils in the states of Rio de Janeiro and São Paulo. The strains AM 01 and AM 07 showed potential for evaluation in network trials aiming the recommendation of new rhizobial strains for the inoculation of peanut.

\section{ACKNOWLEDGEMENTS}

We would like to thank the Universidade Federal Rural do Rio de Janeiro (UFRRJ), Empresa Brasileira de Pesquisa Agropecuária (Embrapa), Conselho Nacional de Desenvolvimento Científico e Tecnológico (CNPq) and the Coordenação de Aperfeiçoamento de Pessoal de Nível Superior (CAPES) for their financial support.

\section{REFERENCES}

Bomfeti CA, Florentino LA, Guimarães AP, Cardoso PG, Guerreiro MC, Moreira, FMS (2011). Exopolysaccharides produced by the symbiotic nitrogen-fixing bacteria of leguminosae. Rev. Bras. Ci. Solo. 35:657671 
Borges WL, Santos CERS, Xavier GR, Rumjanek NG (2007). Nodulação e fixação biológica do nitrogênio de acessos de amendoim com estirpes nativas de rizóbios. Revista Brasileira de Ciências Agrárias. Recife 2:32-37.

Brasil, Ministério da Agricultura, Pecuária e Abastecimento. Instrução Normativa № 13, de 24 de março de (2011). Aprovar as normas sobre especificações, garantias, registro, embalagem e rotulagem dos inoculantes destinados à agricultura, bem como as relações dos micro-organismos autorizados e recomendados para produção de inoculantes no Brasil, na forma dos Anexos I, II e III, desta Instrução. Diário Oficial da República Federativa do Brasil, 25 de mar. 2011. $\begin{array}{llllll}\text { Seção } & 1 . & \mathrm{pp} & 3-7 . & \text { Available }\end{array}$ http://www.in.gov.br/imprensa/visualiza/index.jsp?jornal=1\&pagina $=4$ \&data $=25 / 03 / 2011$

Bushby HVA, Marshall KC (1977). Some factors affecting the survival of root nodule bacteria on desiccation. Soil Biol. Biochem. 9: 143-147

Chagas JAF, Oliveira LA, Oliveira NA, Willerding AL (2010). Capacidade de solubilização de fosfatos e eficiência simbiótica de rizóbios isolados de solos da Amazônia. Acta Scientiarum Agronomy. 32:359-366.

Fernandes Júnior PI, Pereira GMD, Perin L, Silva LM, Baraúna AC, Alves FM, Passos SR, Zilli JE (2013). Diazotrophic bacteria isolated from wild rice Oryza glumaepatula (Poaceae) in the Brazilian Amazon. Revista de Biologia Tropical. 61:991-999.

Fernandes Júnior PI, Silva Junior EB, Silva Junior S, Santos CERS, Oliveira PJ, Rumjanek NG, Martins LMV, Xavier GR (2012). Performance of polymer compositions as carrier to cowpea rhizobial inoculant formulations: Survival of rhizobia in pre-inoculated seeds and field efficiency. Afr. J. Biotechnol. 11:2945-2951.

Fernandes Júnior PI, Lima AA, Passos SR, Gava CAT, Oliveira PJ, Rumjanek NG, Xavier GR (2012) Phenotypic diversity and amylolytic activity of fast growing rhizobia from pigeonpea [Cajanus cajan (L.) Millsp.]. Braz. J. Microbiol. 43:1604-1612.

Fernandes Júnior PI, Almeida JPS, Passos SR, Oliveira PJ, Rumjanek NG, Xavier GR (2010) Produção e comportamento reológico de exopolissacarídeos sintetizados por rizóbios de isolados de guandu. Pesq. Agropec. Bras. 45:1465-1470.

Ferreira DF (2008). Sisvar: um programa para análises e ensino de estatística. Revista Científica Symposium. 6:36-41.

Florentino LA, Sousa PM, Silva JS, Silva KB, Moreira FMS (2010). Diversity and efficiency of bradyrhizobium strains isolated from soil samples collected from around sesbania virgata roots using cowpea as trap species. R. Bras. Ci. Solo. 34:1113-1123.

Freitas ADS, Vieira CL, Santos CERS, Stamford NP, Lyra MCCP (2007). Caracterização de rizóbios isolados de jacatupé cultivado em solo salino do estado de Pernambuco, Brasil. Campinas Bragantia. 66:497-504.

Garcia-Fraile P, Rivas R, Willems A, Peix A, Martens M, MartínezMolina E, Mateos PF, Velázquez E (2007). Rhizobium cellulosilyticum sp. nov., isolated from sawdust of Populus alba. Int. J. Syst. Evol. Microbiol. 57:844-848.

Hara FAS, Oliveira LA (2005). Physiological and ecological characteristics of rhizobia isolates from acid soils of Iranduba, Amazonas. Pesquisa Agropecuária Brasileira. 40:667-672.

Hancock JF (2004). Plant Evolution and the Origin of Crop Species. Massachusetts, CABI Publishing. p. 313.

Hungria M, Andrade DS, Chueire LMO, Probanza A, Guttierrez-Mañero FJ, Megias M (2000). Isolation and characterization of new efficient and competitive bean (Phaseolus vulgaris L.) rhizobia from Brazil. Soil Biol. Biochem. 32:1515-152.

Hungria M, Chueire LMO, Menna P, Bangel EV (2008). Caracterização genética de rizóbios e outras bactérias diazotróficas e promotoras do crescimento de plantas por BOX-PCR. Londrina: Embrapa Soja, p. 12 (Embrapa Soja. Comunicado Técnico, 290).

Hunter WJ, Kuykendall LD, Manter DK (2007). Rhizobium selenireducens sp. nov. a selenite-reducing $\alpha$-Proteobacteria isolated from a bioreactor. Curr. Microbiol. 55:455-460.

Kaschuk G, Hungria M, Andrade DS, Campo RJ (2006). Genetic diversity of rhizobia associated with common bean grown under the no-tillage and conventional systems in Southern Brazil. Appl. Soil Ecol. 32:210-220.

Leite J, Seido SL, Passos SR, Xavier GR, Rumjanek NG, Martins LMV
(2009). Biodiversity of rhizobia associated with cowpea cultivars in soils of the lower half of the São Francisco River Valley. R. Bras. Ci. Solo. 33:1215-1226.

Lima AA, Fernandes Júnior PI, Passos SR, Paulo FS, Nosoline SM, Faria SM, Guerra JGM, Rumjanek NG, Xavier GR (2012). Diversidade e capacidade simbiótica de rizóbios isolados de nódulos de mucuna cinza e mucuna anã. R. Bras. Ci. Solo. 36:337-348.

Liao CFH (1981). Devarda's allow methods for total nitrogen determination. Soil Sci. Soc. Am. J. 45:852-855. Arachis hypogaea L. in Central Argentinean Soils. Plant and Soil. 282:41-52.

Lyra MCCP, Freitas ADS, Silva TA, Santos CERS (2013). Phenotypic and molecular characteristics of rhizobia isolated from nodules of peanut (Arachis hypogaea L.) grown in Brazilian Spodosols. Afr. J. Biotechnol. 12:2147-2156.

Marra LM, Oliveira SM, Soares CRFS, Moreira FMS (2011). Solubilization of inorganic phosphates by inoculant strains from tropical legumes. Sci. Agric. 68:603-609.

Marra LM, Soares CRFS, Oliveira SM, Ferreira PAA, Soares BL, Carvalho RF, Lima JM, Moreira FMS (2012). Biological nitrogen fixation and phosphate solubilization by bacteria isolated from tropical soils. Plant Soil 357:289-307.

Martins LMV, Rangel FW, Xavier GR, Ribeiro JRA, Morgado LB, Neves MCP, Rumjanek NG (2003). Contribution of biological nitrogen fixation to cowpea: A strategy for improving grain yield in the semiarid region of Brazil. Biol. Fert. Soils. 38:333-339.

Martins LMV (1996). Características ecológicas e fisiológicas de rizóbio de feijão-caupi (Vinga unguiculata (L.) Walp) isolados a partir de solos da região Nordeste do Brasil. Seropédica, Universidade Federal Rural do Rio de Janeiro. Dissertação de Mestrado.

Melo EBS (2013). Aspectos fisiológicos do amendoim inoculado com uma estirpe de Bradyrhizobium. Campina Grande, Universidade Estadual da Paraíba. Dissertação de Mestrado.

Nóbrega RSA, Lacerda AM, Motta JS, Moreira FMS (2004). Tolerância de bactérias diazotróficas simbióticas à salinidade in vitro. Ciênc. Agrotecnol. 28:899-905

Norris DO, T'Mannetje L (1964). The symbiotic specialization of African trifolium spp. in relation to their taxonomy and their agronomic use. East Afr. Agric. For. J. 29:214-235.

Santos RC, Freire RMM, Lima LM, Zagonel GF, Costa BJ (2012). Produtividade de grãos e óleo de genótipos de amendoim para 0 mercado oleoquímico. Ciência Agronômica. 43:1-8.

Santos CERS, Stamford NP, Freitas ADS, Neves MCP, Rumjanek N, Souto SM (2005). Efetividade de rizóbios isolados de solos da região nordeste do Brasil, na fixação do N2 em amendoim (Arachis hypogaea). Acta Sci. 27:305-312.

Santos RC, Melo Filho PA, Gomes LR (2007). Produção de amendoim sob diferentes fontes de adubação na Zona da Mata de Pernambuco. Campina Grande. Embrapa (Boletim de pesquisa e desenvolvimento, 85).

Somasegaran P, Hoben HJ (1994). Handbook for rhizobia: Methods in legume Rhizobium technology. Paia: Niftal Project. p. 450.

Stocco P, Santos JCP, Vargas VP, Hungria M (2008). Avaliação da biodiversidade de rizóbios simbiontes do feijoeiro (Phaseolus vulgaris L.) em santa Catarina. R. Bras. Ci. Solo. 32:1107-1120.

Sylvester-Bradley R, Asakawa N, La Torraca S, Magalhães FMM, Oliveira LA, Pereira RM (1982). Levantamento quantitativo de microorganismos solubilizadores de fosfato na rizosfera de gramíneas e leguminosas forrageiras na Amazônia. Acta Amazonica. 12:15-22.

Versalovic J, Schneider M, De Bruijn FJ, Lupski JR (1994). Genomic fingerprinting of bacteria using repetitive sequence-based polymerase chain reaction Meth. Mol. Cell. Biol. 5:25-40.

Vincent GM (1970). Manual of the practical study of root nodule bacteria. (International Biology Program, 15), Oxford: Blackwell p. 163.

Thies JE, Bohlool BB, Singleton PW (1991). Subgroups of cowpea miscellany: symbiotic specificity within Bradyrhizobium spp. for Vigna unguiculata, Phaseolus lunatus, Arachis hypogaea, and Macroptilium atropurpureum. Appl. Environ. Microbiol. 57:1540-1545.

Taurian T, Ibañez F, Fabra A, Aguilar OM (2006). Genetic diversity of rhizobia nodulating the survival of root nodule bacteria on desiccation. Soil Biol. Biochem. 9:143-147. 
Xavier GR, Martins LMV, Rumjanek NG, Neves MCP (2007). Tolerância de rizóbio de feijão caupi à salinidade e à temperatura em condição in vitro. Caatinga. 20: 1-9.

Young JPW, Downer HL, Eardly BD (1991). Phylogeny of the phototrophic Rhizobium strain BTAi1 by polymerase chain reactionbased sequencing of a $16 \mathrm{~S}$ rRNA gene segment. J. Bacteriol. 73:2271-2277.
Zilli JE, Marson LC, Marson BF, Rumjanek NG, Xavier GR (2009). Contribuição de estirpes de rizóbio para o desenvolvimento e produtividade de grãos de feijão-caupi em Roraima. Acta Amazonica. 34:749-758. 